\title{
ZABUDOWA POLANIARSKA JAKO WYRÓŻNIK W BADANIACH NAD TYPOLOGIĄ I GENEZĄ KRAJOBRAZÓW PASTERSKICH POLSKO-UKRAIŃSKIEJ CZĘŚCI KARPAT ZEWNĘTRZNYCH
}

\author{
Janusz Łach \\ Uniwersytet Wrocławski, Wrocław, Polska \\ ORCID: 0000-0001-8451-5957 \\ Ihor Bojko \\ Ukraińska Akademia Nauk, Lwów, Ukraina \\ ORCID: 0000-0002-3828-1835
}

\begin{abstract}
Streszczenie: Artykuł jest próbą wyróżnienia - poprzez osobliwe budownictwo gospodarki polaniarskiej - nowych podtypów krajobrazów pasterskich, jakimi są pastersko-rolne krajobrazy na obszarze niskich i średnich gór Karpat Zewnętrznych. Walory kulturowe obszaru z wołoską genezą klasyfikują go do szczególnie cennych krajobrazowo. To wyjątkowe wspólne dziedzictwo stało się przyczynkiem do podjęcia polsko-ukraińskich badań nad strukturą oraz funkcją górskiej gospodarki w ujęciu etnogeograficznym. Celem działań jest ochrona zanikającego, archaicznego dziedzictwa pasterzy wołoskich nazywanych „Ojcami Europy”.
\end{abstract}

Słowa kluczowe: Karpaty, Beskid Mały, Beskidy Skolskie, pasterstwo, polaniarstwo, kultura wołoska

\section{WSTEP}

Ze względu na reliktowy charakter gospodarki pasterskiej, w szczególności polaniarskiej, na obszarze Karpat polskich, zaistniała nagląca potrzeba przeprowadzenia badań nad kulturowym aspektem materialnego dziedzictwa mieszkańców Karpat Polski i Ukrainy w celu jego ochrony przed zapomnieniem. Z powodu braku żyjących świadków dawnej gospodarki polaniarskiej na obszarze polskich Karpat Zachodnich (m.in. w Beskidzie Małym, Beskidzie Wyspowym i Gorcach) badania nad jej zrozumieniem i odtworzeniem przeniesiono na obszar ukraińskich Karpat Zewnętrznych, gdzie wciąż są prowadzone tradycyjne działania gospodarcze. Korelacja struktury i funkcji gospodarki polaniarskiej jest możliwa ze względu na istnienie wspólnego rdzenia, jakim jest wołoska kultura gospodarcza obszarów górskich. Zamierzeniem wspólnie prowadzonych badań polsko-ukraińskich jest: inwentary- 
zacja obszarów oraz form gospodarki górskiej na polanach $\left(\right.$ holach $\left.{ }^{1}\right)$ typu średniogórskiego, a także analiza porównawcza struktury i funkcji gospodarki polaniarskiej, ze szczególnym uwzględnieniem zabudowy sezonowej w strefie subekumeny.

Zastosowanie metody korelacji pozwoliło na jednoznaczne określenie stosowanej terminologii nazw i funkcji zabudowy pasterskiej w typie gospodarki polaniarskiej na obszarze Zewnętrznych (dawniej Północnych) Karpat polskich i ukraińskich. Do realizacji celów wykorzystano metodę obserwacji terenowej, pozwalającą na inwentaryzację i rejestrację na mapach topograficznych obszarów i typów gospodarki polaniarskiej. Powyższa metoda pozwoliła również na przeprowadzenie wywiadów środowiskowych wśród mieszkańców regionu Beskidu Małego oraz Beskidu Skolskiego, stanowiących obszary studium przypadku. Ze względu na prowadzenie badań w nurcie semiotycznym, do realizacji celów posłużono się metodą wyróżników i wyznaczników krajobrazu dla lepszego wydzielenia typowych elementów krajobrazu².

\section{ROLA OSADNICTWA WOŁOSKIEGO W KSZTAŁTOWANIU KRAJOBRAZÓW KARPAT POLSKICH I UKRAIŃSKICH}

Tradycje pasterskie w całych Karpatach związane są z ludnością wołoską - koczowniczym ludem przybyłym znad Adriatyku, o niewyjaśnionym do dziś pochodzeniu i składzie etnicznym. W XIII stuleciu odnotowano jego obecność na Bałkanach (Bośnia, Serbia, Albania, północna Grecja), skąd wyruszył ku łukowi Karpat w trzech kolejnych falach migracyjnych. Głównym czynnikiem, który najprawdopodobniej stymulował ekspansję Wołochów na północ i zachód, był przyrost naturalny społeczności pasterskich oraz związana z tym konieczność zwiększania stad i zajmowania nowych terenów wypasowych ${ }^{3}$.

\footnotetext{
Hala (hola) - polana powstała wskutek wypalania i karczowania lasów na obszarze leśnym, w celu pozyskania miejsca pod wypas lub uprawę. Genezę polan należy wiązać z rolą osadnictwa wołoskiego kolonizującego łuk Karpacki do czasów średniowiecza. Nazwa „hala” natomiast dotyczy naturalnego piętra alpejskiego z występowaniem łąk wysokogórskich.

2 I. Niedźwiecka-Filipiak, Wyróżniki krajobrazu i architektury wsi Polski poludniowo-zachodniej, Wrocław 2009; Z. Myczkowski, Kompozycyjne i architektoniczne wyznaczniki tożsamości krajobrazów, „Problemy Ekologii Krajobrazu” 2015, t. XL, s. 199-208; U. Myga-Piątek, T. Chmielewski, J. Solon, Rola cech charakterystycznych wyróżników $i$ wyznaczników krajobrazu w klasyfikacji i audycie krajobrazów aktualnych, „Problemy Ekologii Krajobrazu” 2015 , t. XL, s. 177-185.

3 K. Dobrowolski, Badania nad ugrupowaniami etnograficznymi w Karpatach Zachodnich, „Sprawozdania z czynności i posiedzeń Polskiej Akademii Umiejętności” 1938, t. 43, nr 5, s. 181-229; Idem, Studia nad kultura pasterska w Karpatach Pótnocnych, typologia wędrówek pasterskich od XIV do XX wieku, [w:] Pasterstwo Tatr Polskich i Podhala, pod red. W. Antoniewicz, t. VIII, Wrocław - Warszawa - Kraków 1970, s. 98-120; G. Jawor, Ethnic aspects
} 
Pierwsza fala wołoska, bardzo nieliczna, dotarła do łuku Karpat Wschodnich prawdopodobnie pod koniec XIII i na początku XIV wieku. Druga, liczniejsza fala wołoska, przybyła na obszar Karpat Zachodnich na przełomie XV i XVI wieku, a trzecia w XVII stuleciu ${ }^{4}$.

Wołosi to określenie szeregu archaicznych grup etnicznych, które funkcjonowały w ramach klanowej struktury plemiennej i nigdy nie wykształciły własnej tożsamości narodowej ${ }^{5}$. Stanowili oni wędrowny lud pasterski, który na skutek ciągłego przemieszczania się uległ rozproszeniu. W trakcie wędrówek stopniowo wtapiali się w napotkane na swej drodze lokalne społeczeństwa, zatracając stopniowo cechy wspólnoty plemiennej i przejmując nowe wzorce ${ }^{6}$. Mimo tych przemian, jako wspólnota pierwotnie pasterska, odznaczali się pewną hermetycznością oraz przywiązaniem do własnej tradycji. Dzięki temu relikty owej pierwotnej wspólnoty są do dziś widoczne wśród licznych współczesnych grup zamieszkujących Karpaty. Na terenie Karpat Wołosi wnieśli istotny wkład w formowanie wspólnoty kulturowej grup etnicznych takich jak: Górale polscy (od Górali śląskich na zachodzie po Górali sądeckich na wschodzie), Górale ruscy (Łemkowie, Bojkowie, Huculi), Wołosi morawscy i słowaccy, przekazując im górski system gospodarki pasterskiej, wzorce kulturowe i słownictwo ${ }^{7}$. Wejście etnicznych Wołochów na nowe terytoria i tym samym nieuchronna konfrontacja $z$ innym żywiołem etnicznym zazwyczaj kończyły się rozciągniętą na czas życia kilku pokoleń całkowitą asymilacją przybyszów ${ }^{8}$. Pod koniec XVI wieku dokonała się na obszarze Karpat zmiana typu gospodarowania $\mathrm{z}$ transhumancji na letni wypas górski, który przyczynił się do zatrzymania się wędrówki osadników

of settlement in Ius Valachicum in medieval Poland (from the 14th to the beginning of the 16th century), „Balcanica Posnaniensia” 2015, t. XXII/I, Ius Valachicum I, Poznań - Bucharest 2015, s. 47-55.

$4 \quad$ K. Dobrowolski, Studia nad kultura pasterska w Karpatach Pótnocnych; I. Czamańska, The Vlachs - several research problems, „Balcanica Posnaniensia” 2015, t. XXII, nr 1, Ius Valachicum I, Poznań - Bucharest 2015, s. 7-16.

5 I. Czamańska, op. cit.

6 Zob. K. Dobrowolski, Studia nad kultura pasterska w Karpatach Pótnocnych; K. Moszyński, Kultura ludowa Stowian, Warszawa 1967; Idem, Ludy pasterskie ich kultura materialna oraz podstawowe wiadomości o formach wspólżycia zbiorowego, o wiedzy, życiu religijnym i sztuce, Cieszyn 1996.

J. Gudowski, M. Ząbek, H. Konarski, A. Kosiek, M. Kropiwnicki, J. Nesteruk, A. Ruszczak, W. Witkowski, W. Żakowski, Pasterstwo na Huculszczyźnie. Gospodarka, kultura, obyczaj, Warszawa 2001; M. Musiał, Śladami kultury góralskiej w Beskidzie Małym, Andrychów 2010; I. Czamańska, op. cit.; G. Jawor, op. cit.; I. Бойко, Я. Лях, Адаптивні стратегіï традиційного сезонного будівництва на полянах та пасовиськах у Північних Карпатах (кінець XIX - перша половина XX століття), „Матеріали до української етнології” 2016, Вип. 15, s. 47-56.

$8 \quad$ J. Łach, M. Musiał, Przeszłość i znaczenie tradycji dla współczesnego oblicza kulturowego góralszczyzny Beskidu Małego - zapis w krajobrazie, Wrocław 2015. 
wołoskich ${ }^{9}$. Osiedlanie się pasterzy wołoskich miało znaczący wpływ na krajobraz przyrodniczy: w wyniku karczowania lasu powstawały śródleśne polany, ze względu na brak piętra alpejskiego na obszarze niskich i średnich gór, ścieżki, dukty, a następnie idąca z zagospodarowaniem zabudowa gospodarcza oraz mieszkalno-gospodarcza. Nowo powstały krajobraz wzbogacał skromne ekosystemy dzięki możliwości bytowania nowych gatunków roślin i zwierząt, a materialne dziedzictwo osadników wołoskich na trwałe zmieniło krajobraz karpacki.

\section{FORMY GOSPODARKI PASTERSKO-ROLNEJ NA OBSZARZE KARPAT POLSKICH I UKRAIŃSKICH JAKO WYRÓŻNIK TOŻSAMOŚCI KRAJOBRAZOWEJ}

Na obszarze Karpat główną formą gospodarowania górskiego było/jest (czas przeszły dotyczy obszaru Karpat polskich, natomiast teraźniejszy obszaru Karpat ukraińskich) pasterstwo wędrowne określane jako szałaśnictwo oraz działania pastersko-rolne zwane polaniarskimi.

Pasterstwo wędrowne - szalaśnictwo - charakteryzuje się przebywaniem ze stadem zwierząt poza miejscowością zamieszkiwania przez określoną część roku w celu mobilnego wypasu na łąkach pastwiskowych oraz pozyskania i przetworzenia na miejscu surowca mlecznego ${ }^{10}$. Gospodarka polaniarska natomiast charakteryzuje się bardziej zróżnicowaną strukturą niż szałaśnictwo. Podstawą eksploatacji jest w tym przypadku indywidualna - stacjonarna, a nie społeczna własność polan, na których główną funkcją była produkcja paszy (siana), wypas zwierząt, w mniejszym stopniu produkcja rolna ${ }^{11}$. W obrębie poszczególnej parceli większa powierzchnia użytkowana była/jest wykorzystywana jako łąka kośna lub pastwisko, mniejsza - pod uprawę, w zależ-

9 Z. Hołub-Pacewiczowa, Z badań nad pasterstwem karpackim i alpejskim, „Czasopismo Wierchy” 1930, t. VIII, s. 89-121; B. Kopczyńska-Jaworska, Wędrówki pasterskie w Beskidzie Śląskim, „Etnografia Polska” 1961, t. V, s. 227-231; J. Novák, J. Podolák, I. Zuskinová, M. Margetín, Po stopách valachov v Karpatoch, Brno 2013; M. Sobala, Krajobrazy pasterskie w Polsce i Europie - wybrane typy, przyktady i formy ochrony, „Prace Komisji Krajobrazu Kulturowego" 2014, t. 25, s. 81-98.

10 B. Kopczyńska-Jaworska, Dyskusyjne problemy syntezy badań nad pasterstwem wysokogórskim, „Etnografia Polska” 1981, t. XXV, z. 2, s. 85-96; J. Novak, J. Podolak, I. Zuskinova, M. Margetin, op. cit.; W. Antoniewicz, Pasterstwo Tatr Polskich i Podhala, t. 1-8, Wrocław Warszawa - Kraków 1959-1970.

11 E. Dorywalska, Badania nad pasterstwem i gospodarka polaniarska na Żywiecczyźnie, „Karta Groni: wydawnictwo społeczno-kulturalne poświęcone sprawom Żywiecczyzny i Beskidów” 1974, s. 52-56; E. Zawiejska, Budownictwo pasterskie w Beskidzie Żywieckim, „Prace i Materiały Muzeum Archeologicznego i Etnograficznego w Łodzi” 1986, Seria Etnograficzna, nr 26, s. 39-55. 
ności od indywidualnej decyzji właściciela. W strukturze organizacji działań można było/można wyróżnić dwie formy gospodarowania, tj. wypas dzienny oraz wypas sezonowy (pośredni pomiędzy szałaśnictwem a polaniarstwem), charakteryzujący się kilkutygodniowym (od maja/czerwca do września) pobytem na polanie lub polanach tego samego właściciela (Ryc. 1).

\section{GOSPODARKA PASTERSKA}

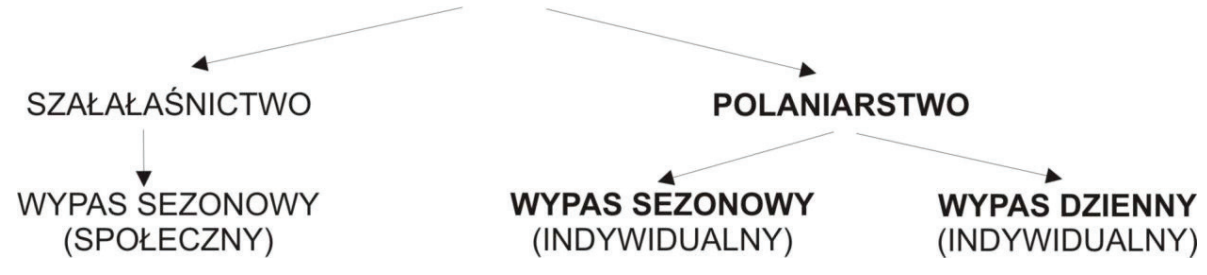

Ryc. 1. Typy gospodarki pasterskiej na obszarze Karpat polskich i ukraińskich pod koniec XX wieku. Źródto: opracowanie własne.

Fig. 1. Types of pastoral economy in the Polish Carpathians at the end of the $20^{\text {th }}$ century. Source: author's study.

Wypas dzienny charakteryzował się wyprowadzaniem bydła i owiec na polany w ciągu dnia, a następnie sprowadzeniem zwierząt na nocleg do obory, natomiast wypas sezonowy był/jest bliższy tradycji szałaśniczej. W przypadku pozostania na polanie funkcję opieki nad niewielką ilością zwierząt przejmowała jedna dorosła osoba (pasterz) mająca do dyspozycji kilku pomocników należących do rodziny oraz ochronę w postaci psa pasterskiego. Do koszenia trawy oraz do prac polowych dochodziły osoby dorosłe - krewni z rodziny właściciela polany oraz sąsiedzi. W zależności od tego, jakie funkcje gospodarcze pełniły w określonym roku polany, można wyznaczyć dwa typy ich użytkowania: typ hodowlano-sianokośny oraz hodowlano-sianokośno-uprawny. Typ pierwszy - dominujący w strukturze działań gospodarskich - obejmował wypas połączony z hodowlą oraz z jednoczesną produkcją surowca roślinnego, jakim jest siano. Obok wypasu i dozoru stada główną powinnością pasterzy było dojenie owiec (dwa razy dziennie). Dopiero późnym latem i jesienią, kiedy dzień był już bardzo krótki, a trawa mało kaloryczna, owce dojono tylko raz dziennie. Ze względu na formę prowadzenia zajęć pastersko-rolniczych na polanach śródleśnych raz, czasami dwa razy do roku koszono twardą trawę zwaną szczotką lub skuciorą. Gotową do koszenia trawę żęło kosami do dziesięciu chłopów, zwykle po rosie lub po deszczu. Skoszoną trawę, która jeszcze nie miała postaci siana, a którą należało chronić przed deszczem, kobiety i mężczyźni zgrabiali na kopce - klabnioki ${ }^{12}$ lub

12 Klabniok - sterta siana ułożona na łące bez ostrewki. 
przy pomocy ostrewki formowali snopki (kopy) ${ }^{13}$. Gdy uzyskano siano o odpowiedniej wilgotności, jego część układano w stóg lub bróg (ukr. oborog - оброг) na obszarze Beskidów Skolskich lub chowano do szop na polanach w Beskidzie Małym. Nadmiar siana zwożono do wsi wozem drabiniastym lub, w okresie zimowym, saniami. Dla zabezpieczenia koni przed zderzeniem z wozem z tyłu wiązano dwa lub trzy nieokrzesane drzewa - świerki lub buki. Była to tak zwana zwłać, która zabezpieczała furę przed wywróceniem.

Drugi typ użytkowania obejmował zadania wymienione w typie pierwszym, jednak uzupełnione dodatkowo o uprawę owsa, żyta, ziemniaków i buraków. W strukturze użytkowej polany około $1 / 3$ powierzchni przeznaczona była pod uprawę, która $\mathrm{w}$ zależności od potrzeb była prowadzona przez 2-3 lata, po czym pole przeznaczano pod łąkę i użyźniano nawozem zwierzęcym przez kolejne 2-3 lata. Poletka uprawne grodzono prymitywnym drewnianym, rzadziej kamiennym płotem, chroniącym pole przed zwierzętami gospodarskimi oraz leśnymi.

W gospodarce polaniarskiej zasadnicze znaczenie miał wypas bydła i owiec na skoszonych łąkach, pozwalający na nawożenie gleby. Wczesną wiosną, kiedy zwierzęta wyjadły już trawę wokół domostw, wyprowadzano je na górskie łąki oddalone od gospodarstw o około 1-2 godziny drogi, na których pojawiała się świeża trawa. Uciążliwość codziennego prowadzenia zwierząt na wypas, uwarunkowana stromymi zboczami i kamienistymi drogami, spowodowała, że pasterze wyprowadzali zwierzęta na okres od miesiąca do dwóch miesięcy, co pozwalało na odrastanie traw na łąkach położonych w pobliżu wsi.

$\mathrm{Na}$ wysoko położonych polanach pasterze zakładali stacjonarny zespól zabudowy polaniarskiej (Tab.1). Zespół polaniarski tworzyły/tworzą budynki o różnych funkcjach: w regionie Beskidu Małego Karpat Zachodnich jest to głównie szopa polaniarska typu fenil, pełniąca funkcję magazynu na siano i sprzęt rolniczy (szopa/salasznik), szopa pastwiskowa/inwentarska (krowiarka) pełniąca funkcję schronienia dla zwierząt i dysponująca systemem odprowadzania obornika, lecz nie posiadająca strychu i urządzeń do karmienia oraz nocowania zwierząt, drewniany koszor, kamienny murek zwany krudą, prymitywny szałas (zastajka) sprawujący funkcję strażnicy i schronienia dla pasterzy, drewniana bacówka (staja) lub kamienna izbica jako miejsce przetwarzania surowca mlecznego oraz miejsce nocowania pasterzy na polanach polaniarskich (w Beskidzie Małym bardzo rzadka według Zofii Hołub-Pacewicz wielka osobliwość etnograficzna regionu).

W regionie Beskidów Skolskich Karpat Wschodnich zespół uzupełniają: drewniana koliba będąca miejscem schronienia i nocowania dla pasterzy,

\footnotetext{
13 Snopek - sterta siana ułożona na ostrewce, czyli pniu drzewa świerkowego z bocznymi odnogami.
} 
koliba sianokośna pełniąca funkcję schronienia dla człowieka na polanach sianokośnych, szopa sianokośna (siennik), czyli magazyn na siano (charakteryzujący się brakiem drzwi i okien oraz systemem wrzutu siana znajdującym się w ścianie szczytowej powyżej 3-4 zrębu) oraz obora sezonowa - zabudowa przeznaczona dla zwierząt, w której nocowało się i jadło; jej istotnym elementem jest drewniana podłoga, systemem odprowadzania obornika oraz strych na siano. Najważniejszą, centralną zabudową zespołu polaniarskiego regionu Karpat Wschodnich jest sezonowa dwu- lub trzyizbowa chata z sienią, boiskiem oraz strychem. Chata pełni funkcję mieszkalno-gospodarczą, w izbie głównej znajduje się piec oraz urządzenia kuchenne ${ }^{14}$.

\begin{tabular}{|l|c|c|}
\hline \multicolumn{1}{|c|}{ Typ zabudowy polaniarskiej } & $\begin{array}{c}\text { Beskid Mały - Karpaty } \\
\text { Zachodnie }\end{array}$ & $\begin{array}{c}\text { Beskidy Skolskie - } \\
\text { Karpaty Wschodnie }\end{array}$ \\
\hline szopa typu fenil & TAK & TAK \\
\hline szopa pastwiskowa/inwentarska & TAK & TAK \\
\hline szopa sianokośna & NIE & TAK \\
\hline obora sezonowa & NIE & TAK \\
\hline Koszor & TAK & NAK \\
\hline kruda - kamienne murki & TAK & TAK \\
\hline stóg lub bróg & NIE & TAK \\
\hline prymitywny szałas & TAK & TAK \\
\hline drewniana koliba & TAK & TAK \\
\hline sianokośna koliba & NIE & TAK \\
\hline izbica & SPORADYCZNIE & TAK \\
\hline chata sezonowa & NIE & \\
\hline
\end{tabular}

Tab. 1. Zespół zabudowy polaniarskiej na obszarze Karpat Zachodnich i Wschodnich. Źródto: opracowanie własne.

Tab. 1. The agro-shepherd buildings in the Western and Eastern Carpathians. Source: author's study.

Zespół zabudowy polaniarskiej wraz z prowadzonymi działaniami gospodarskimi na polanie śródleśnej charakteryzuje się dwoma typami strukturalno-funkcjonalnymi: typ I znamionuje struktura pastwiskowo-łąkowa, typ II zaś, bardziej złożony, struktura pastwiskowo-łąkowo-uprawna. Te dwa typy tworzą specyficzny układ architektoniczno-krajobrazowy Karpat Zewnętrznych, różniący się miedzy sobą lokalizacją i liczbą zabudowy tworzącej zespół polaniarski. W Karpatach polskich zespół liczący do 6 elementów lokowano na skraju polany, natomiast w Karpatach ukraińskich zespół liczący 11 elementów - na jej środku (Ryc. 2).

14 І. Бойко, Я. Лях, Адаптивні стратегї традиційного сезонного будівнииттва на полянах та пасовиськах у Північних, ор. cit. 

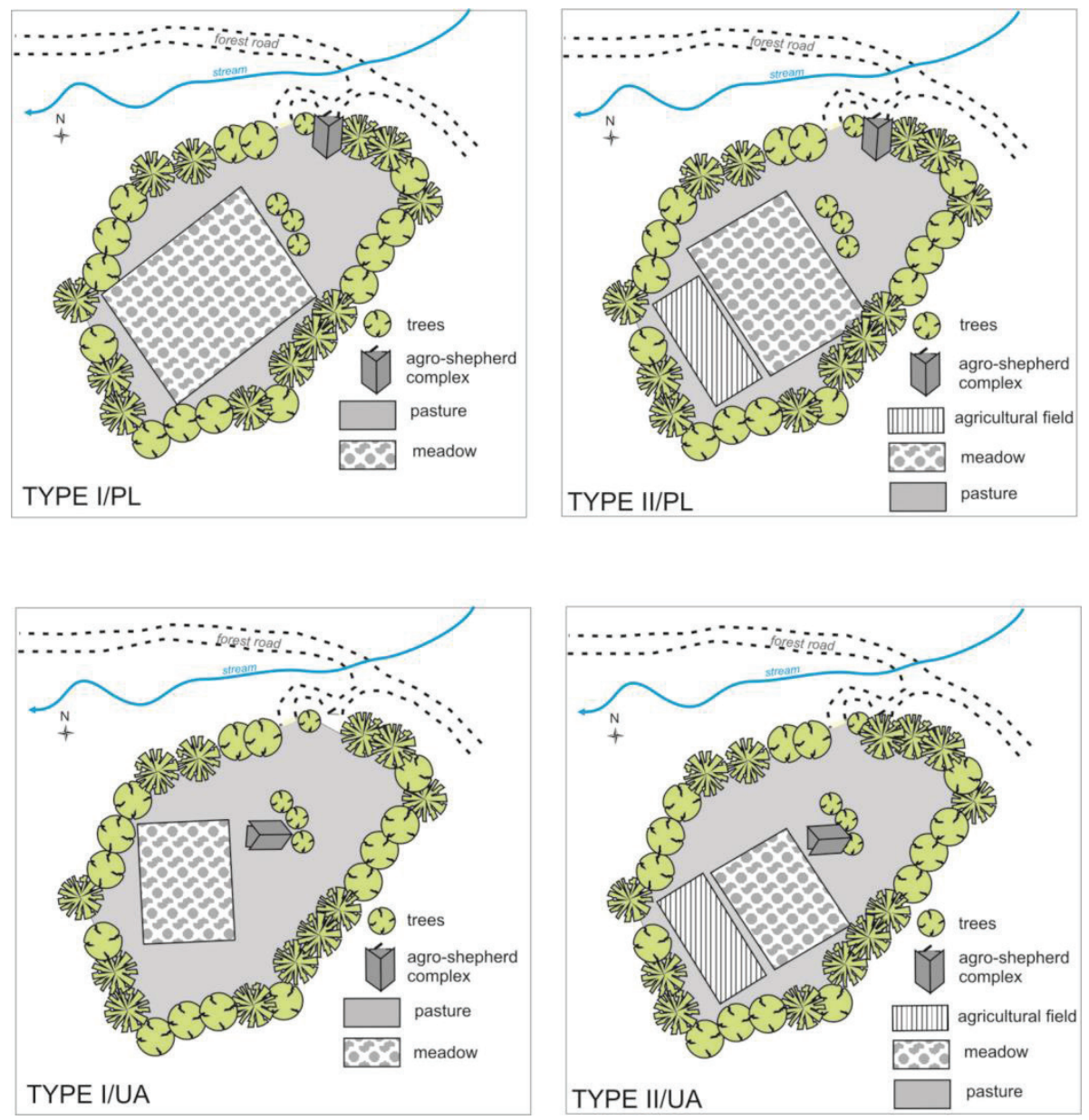

Ryc. 2. Układy architektoniczno-krajobrazowe powstałe w wyniku ewolucji gospodarki polaniarskiej. Źródło: opracowanie własne.

Fig. 2. Architectural-landscape layouts created through evolution of agro-shepherd economy Source: author's study.

\title{
SZOPY I KOLIBY POLANIARSKIE JAKO IDENTYFIKATOR GÓRALSKIEGO KRAJOBRAZU KULTUROWEGO KARPAT ZEWNĘTRZNYCH
}

\author{
KARPATY POLSKIE - BESKID MAŁY \\ (PÓŁNOCNA ŻYWIECCZYZNA - REGION ETNOGRAFICZNY)
}

Obecnie na obszarze Beskidu Małego nie prowadzi się gospodarki polaniarskiej, jedyną pozostałością po niej są już tylko nieliczne, znacznie zniszczone szopy (typu fenil) oraz kamienne izbice. Cechą charakterystyczną dla 
regionu północnej Żywiecczyzny były szopy jednoizbowe z dachem dwuspadowym o konstrukcji krokwiowo-jętkowej, krytym gontem, darnicą lub blachą ${ }^{15}$. Dach osadzony był na ścianach z bali lub na kamiennych ścianach. Wejście do szopy, najczęściej wąskofrontowe, zamykane było drewnianymi drzwiami na kutych zawiasach z metalową zasuwą lub metalowym skoblem. We wnętrzu znajdowało się klepisko i pniak służący jako stolik, a na ścianach haki wykonane z gwoździ; sufit tworzyły trzy lub cztery belki służące do przechowywania siana na strychu. Cechą charakterystyczną budowli był brak okien oraz dymnika, co świadczyło o głównej funkcji użytkowania, jaką było magazynowanie siana ${ }^{16}$. Budynki tego regionu posiadały zbliżoną kubaturę $12 \mathrm{~m}^{2}$. Jej wyróżnikiem było pojedyncze występowanie na skraju śródleśnych polan stokowych na wysokości od 450 do 880 m n.p.m. Na podstawie przeprowadzonej analizy konstrukcyjno-architektonicznej wyróżniono trzy typy zabudowy polaniarskiej regionu Beskidu Małego: szopa kamienna (Fot. 1), szopa drewniano-kamienna oraz szopa drewniana ${ }^{17}$. Wszystkie szopy

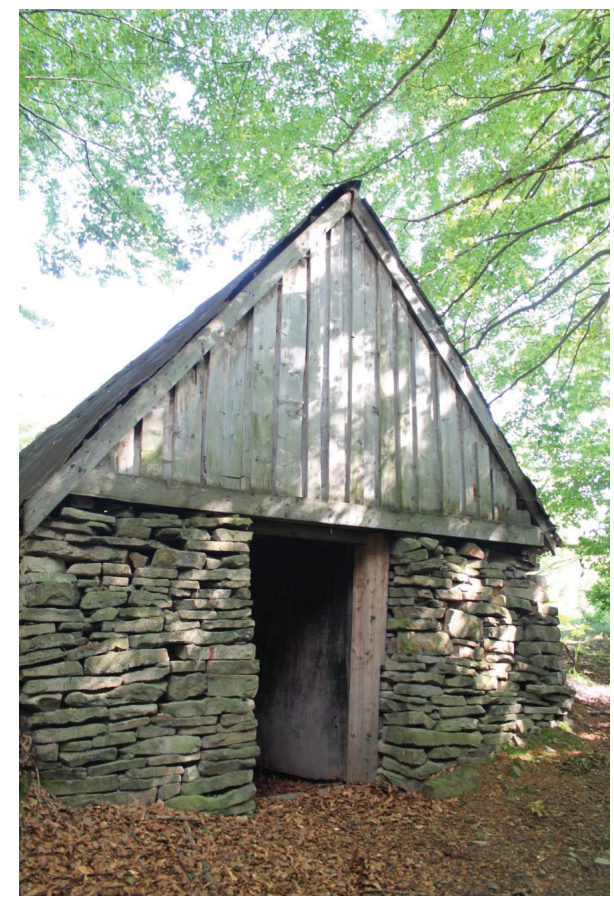

Fot. 1. Unikatowa konstrukcja kamiennej szopy w paśmie Kiczery - Beskid Mały.

Photo 1 . The unique construction of a stone shed in the Kiczera range - the Little Beskid.

\footnotetext{
15 E. Dorywalska, op. cit.; E. Zawiejska, op. cit.; J. Łach, M. Musiał, op. cit.

16 J. Łach, Kamienne szopy pasterskie jako ginacy element krajobrazu Beskidu Matego, „Czasopismo Wierchy” 2010, t. 76, s. 244-249.

17 J. Łach, M. Musiał, op. cit.
} 
były lokowane na polanach, głównie o ekspozycji południowej i południowo-zachodniej, w linii drzew otaczających polanę w celu ochrony przed wiatrem i śniegiem. Ważnym elementem $\mathrm{w}$ strukturze polany była droga leśna przecinająca rzekę lub biegnąca w pobliżu oraz bliskości wody. Miejsce poboru wody zazwyczaj znajdowało się w odległości od 30 do 150 metrów od polany.

\section{KARPATY UKRAIŃSKIE - BESKIDY SKOLSKIE \\ (WSCHODNIA BOJKOWSZCZYZNA - REGION ETNOGRAFICZNY)}

Współcześnie zabudowa polaniarska na obszarze Beskidów Skolskich jest obecna w krajobrazie ze względu na prowadzone działania pastersko-rolnicze głównie o typie subekumeny - tworzyć ją może nawet 11 obiektów o funkcjach magazynowych dla siana i płodów rolnych, jak też i schronienia dla zwierząt i pasterzy ${ }^{18}$.

Zespół polaniarski regionu lokowany jest głównie na polanach stokowych, rzadko natomiast na polanach grzbietowych. Pośrodku polany stoi chata sezonowa, a w jej pobliżu pozostałe obiekty zabudowy, tj. izbica, szopa typu fenil, szopa sianokośna i obora sezonowa (Fot. 2). W odległości kilkuset metrów od centralnego zespołu stoi: krowiarka, drewniana koliba, szałas-strażnica, koliba sianokośna oraz kosor. Na podstawie badań prowadzonych przez I. Bojkę ${ }^{19}$ dowiadujemy się, że zabudowa polaniarska charakteryzuje się drewnianą architekturą o konstrukcji zrębowej. Budynki, poza chatą i oborą sezonową, mają niewielką powierzchnię $\left(8-12 \mathrm{~m}^{2}\right)$, a ich pokrycie stanowił zazwyczaj darnicowy dach dwuspadowy. Konstrukcja zrębowa osadzona jest na belkach kilka centymetrów nad ziemią - brak jest kamiennych fundamentów ze względu na kruchość skały piaskowcowej. Ściany budynku tworzy od siedmiu do dziesięciu belek ułożonych na zrąb.

Szopy nie posiadają okien oraz dymnika, wejście wąskofrontowe tworzą drewniane drzwi usadowione symetrycznie. Spośród szop polaniarskich to właśnie szopy inwentarskie (krowiarki) w architekturze wzbogacone są

\footnotetext{
18 М. Тиводар, Традииійне скотарство украӥнських Карпат другої половини XIX-першої половини XX cm., Ужгород 1994, s. 305-329; I. Bojko, Letnie obory w Karpatach ukraińskich i zachodnich: etnoekologiczne podobieństwa w kulturach Ukraińców, Stowaków, Polaków i Czechów, [w:] Łemkowie, Bojkowie, Rusini-historia, współczesność, kultura materialna i duchowa, red. B. Halczak, S. Dudra, R. Drozd, M. Sopoliga, A. Izhevskyy, O. Kuzmenko, L. Horoshko, P.J. Best, E. Ładna, M. Šmigel, t. V, Słupsk - Zielona Góra - Svidnik 2015, s. 361-376.

19 I. Bojko, Letnie obory w Karpatach ukraińskich i zachodnich: etnoekologiczne podobieństwa w kulturach Ukrainców, Stowaków, Polaków i Czechów...; I. Бойко, Я. Лях, Адаптивні стратегії традиційного сезонного будівництва на полянах та пасовиськах у Північних Карпатах (кінець XIX - перша половина ХХ століття)...
} 
o małe okna, wycięte w jednej z belek zrębu, oraz asymetryczne wejście. Szopy budowane są najczęściej na polanach położonych na wysokościach od 600 do 1100 m n.p.m., oddalonych od 100 do 1500 metrów od centralnego zespołu polaniarskiego (jakim jest chata sezonowa), w pobliżu drogi i źródła wody.

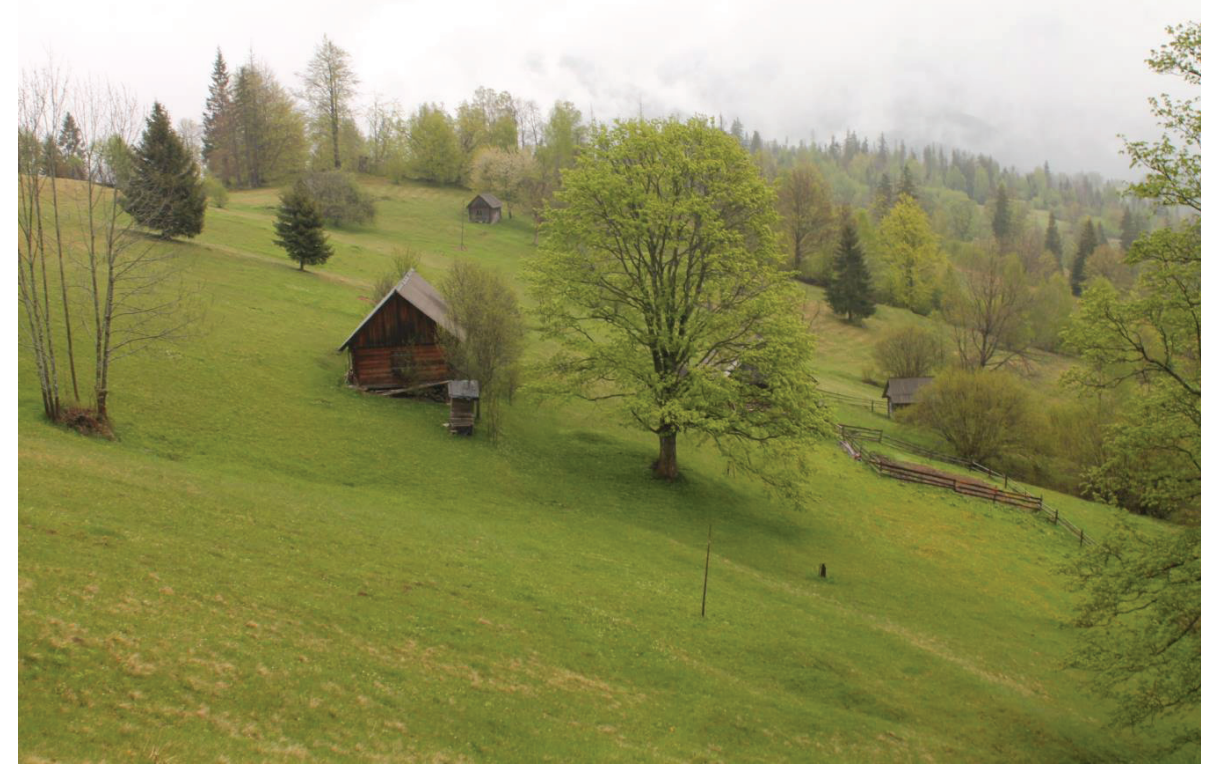

Fot. 2. Zespół zabudowy polaniarskiej na polanie stokowej. Widoczna chata sezonowa na horyzoncie izbica, zaś po prawej szopa typu fenil (Fot. I. Bojko).

Photo. 2. The agro-shepherd complex in a clearing slope. Visible seasonal hut on the horizon there is izbica, and on the right of the fenil shed (Photo: I. Bojko).

Koliby Beskidów Skolskich charakteryzują się dwoma typami konstrukcyjnymi. Pierwszy typ archaiczny to koliba (szałas półdaszkowy) zbudowana z wąskich bali wspartych na drewnianej poręczy zwanej ślemię, której dach tworzą deski, gałęzie lub folia. Drugi typ to konstrukcja drewniana, zrębowa z dwuspadowym, drewnianym lub słomianym, dachem. We wnętrzu obiektu, oprócz miejsca do spania, znajduje się strych wykorzystywany jako magazyn na siano. Wąsko- lub szerokofrontowe wejście do budynku zamykają drewniane drzwi. Wnętrze jest urządzone bardzo skromnie - $\mathrm{z}$ wydzielonym miejscem do spania dla pasterza oraz do przechowywania urządzeń pastersko-rolniczych. Obiekty posiadają okna, ale są pozbawione paleniska. Zabudową, w której przebywają pasterze i rolnicy o wyższym standardzie, jest izbica ${ }^{20}$.

20 I. Bojko, Letnie obory w Karpatach ukraińskich i zachodnich: etnoekologiczne podobieństwa w kulturach Ukraińców, Stowaków, Polaków i Czechów... 
W tym typie koliby znajdują się okna, dymnik, piec i miejsca do spania, można tu także wyróżnić sień oraz izbę. Koliby o funkcji mieszkaniowej znajdują się w odległości do kilkuset metrów, natomiast izbice do kilku kilometrów od centralnego zespołu, w pobliżu źródła wody oraz drogi, pozwalających prowadzić przetwórstwo surowca mlecznego na miejscu.

\section{PODSUMOWANIE}

Krajobraz Karpat, w tym Karpat Zewnętrznych, jest dynamiczną matrycą o złożonej strukturze przyrodniczo-kulturowej, kształtowanej od średniowiecza przez osadników wołoskich. W związku z uwarunkowaniami przyrodniczymi mającymi wpływ na asymilację z ludnością rolniczą, zmienili oni swój styl życia ewoluując z typu pasterstwa wędrownego na pasterstwo osiadłe łączące cechy typowego pasterstwa $\mathrm{z}$ tradycyjnym rolnictwem. W procesie podporządkowania się lokalnej kulturze, przejmowali ich zwyczaje oraz styl, ale także przekazywali swoje doświadczenia kulturowe i umiejętności, m.in. w budownictwie gospodarczym i mieszkaniowym. To właśnie zabudowa gospodarcza w postaci stałej zabudowy polaniarskiej, ze względu na swoje funkcje i przeznaczenie, przetrwała do dnia dzisiejszego i dzięki temu niememu świadkowi możemy odtwarzać i interpretować dziedzictwo etniczne i krajobrazowe poszczególnych regionów Karpat, w tym Karpat Zachodnich, gdzie obecnie pasterstwo ma status reliktowy lub formę wypasu kulturowego.

Jak wykazały prowadzone pionierskie badania etnogeograficzne na obszarze średnich gór pasm karpackich, kultura wołoska, łącząc się z lokalnymi kulturami, organizowała gospodarkę pastersko-rolną na polanach śródleśnych (sztucznych halach). Wypas, pozyskanie surowca mlecznego, siana oraz uprawa, miała/ma charakter działań stacjonarnych, prowadzonych przez jednego gospodarza, który na czas zajęć sezonowych stawiał tak zwany zespół zabudowy polaniarskiej, na który składało się od sześciu do jedenastu obiektów o funkcji gospodarczo-mieszkaniowej, magazynowej lub schronienia. Zespół ten jest zatem wyróżnikiem w identyfikacji rodzaju kultury działań gospodarskich pastersko-rolniczych na obszarze średnich pasm Karpat Zewnętrznych. Działań, dodajmy, o charakterze letniego wypasu pozwalających na wydzielenie wśród krajobrazów pasterskich podtypu, jakim jest krajobraz polaniarski (Ryc. 3).

Na tym etapie opracowania krajobrazy polaniarskie możemy zaliczyć do grupy krajobrazów przyrodniczo-kulturowych, ukształtowanych w wyniku wspólnego działania procesów naturalnych, jak też i świadomych modyfikacji pokrycia terenu górskiego przez człowieka. Badania pozwoliły na wykazanie silnych, kilkuwiekowych wpływów kultury wołoskiej na zachowanie ar- 
chaicznych działań gospodarczych w strefie polan górskich w paśmie Karpat Zewnętrznych polskich i ukraińskich. Pomimo zaistniałych zmian gospodarczych, społecznych i narodowościowych zachodzących w XX wieku, badania te ukazują, jak wiele nas łączy i jak dużo na płaszczyźnie etnogeograficznej jest jeszcze do zbadania.

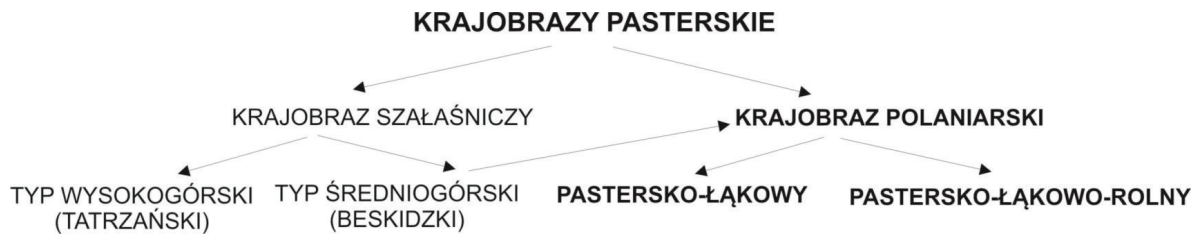

Ryc. 3. Typologia krajobrazów pasterskich na obszarze Karpat. Źródto: opracowanie własne.

Fig. 3. Typology of pastoral landscapes in the Carpathians. Source: author's study.

\section{BIBLIOGRAFIA}

Antoniewicz Włodzimierz. 1959-1970. Pasterstwo Tatr Polskich i Podhala t. 1-8. Wrocław - Warszawa - Kraków: Zakład Narodowy imienia Ossolińskich - Wydawnictwo Polskiej Akademii Nauk.

Bojko İgor, Lâh Ânuš. 2016. Adaptivnì strategï tradicìnogo sezonnogo budivnictva na polânah ta pasovis'kah u Pivničnih Karpatah (kinec' XIX - perša polovina XX stolittâ). „Materìali do ukraïns'koï etnologiï” Vip. 15: 47-56 [Бойко Ігор, Лях Януш. 2016. Адаптивні стратегії традииійного сезонного будівництва на полянах та пасовиськах у Північних Карпатах (кінець ХІХ - перша половина ХХ століття). „Матеріали до української етнології” Вип. 15: 47-56].

Bojko Igor. 2015. Letnie obory $w$ Karpatach ukrainskich i zachodnich: etnoekologiczne podobieństwa w kulturach Ukraińców, Stowaków, Polaków i Czechów. W: Łemkowie, Bojkowie, Rusini - historia, współczesność, kultura materialna i duchowa t. V. Red. Halczak B., Dudra S., Drozd R., Sopoliga M., Izhevskyy A., Kuzmenko O., Horoshko L., Best P.J., Ładna E., Šmigel M. Słupsk - Zielona Góra - Svidnik: Wydawnictwo Uniwersytetu Zielonogórskiego: 361-376.

Chmielewski Tadeusz, Myga-Piątek Urszula, Solon Jerzy. 2015. Typologia aktualnych krajobrazów Polski. „Przegląd Geograficzny” 87, t. III: 377-408.

Czamańska Ilona. 2015. The Vlachs - several research problems, „Balcanica Posnaniensia" vol. 22, nr 1: 7-16.

Dobrowolski Kazimierz. 1938. Badania nad ugrupowaniami etnograficznymi w Karpatach Zachodnich. „Sprawozdania z czynności i posiedzeń Polskiej Akademii Umiejętności” t. 43, nr 5: 181-229.

Dobrowolski Kazimierz. 1970. Studia nad kultura pasterska w Karpatach Pótnocnych, typologia wędrówek pasterskich od XIV do XX wieku. W: Pasterstwo Tatr Polskich $i$ Podhala. Red. Antoniewicz W. Wrocław - Warszawa - Kraków: Zakład Narodowy imienia Ossolińskich - Wydawnictwo Polskiej Akademii Nauk t. VIII: 98-120. 
Dorywalska Ewa. 1974. Badania nad pasterstwem i gospodarka polaniarska na Żywiecczyźnie. „Karta Groni: wydawnictwo społeczno-kulturalne poświęcone sprawom Żywiecczyzny i Beskidów": 52-56.

Gudowski Janusz, Ząbek Maciej, Konarski Henryk, Kosiek Anna, Kropiwnicki Michał, Nesteruk Jura, Ruszczak Andrzej, Witkowski Włodzimierz, Żakowski Władysław. 2001. Pasterstwo na Huculszczyźnie. Gospodarka, kultura, obyczaj. Warszawa: Wydawnictwo Akademickie Dialog.

Hołub-Pacewiczowa Zofia. 1930. Z badań nad pasterstwem karpackimi alpejskim. „Czasopismo Wierchy" t. VIII: 89-121.

Jawor Grzegorz. 2015. Ethnic aspects of settlement in Ius Valachicum in medieval Poland (from the $14^{\text {th }}$ to the beginning of the $16^{\text {th }}$ century). „Balcanica Posnaniensia” $t$. XXII, nr 1: 47-55.

Kopczyńska-Jaworska Bronisława. 1961. Wędrówki pasterskie w Beskidzie Ślaskim. „Etnografia Polska" t. V: 227-231.

Kopczyńska-Jaworska Bronisława. 1962. Szałaśnictwo w Karpatach Polskich $w$ świetle prac zespołowych w roku 1960. „Etnografia Polska” t. VI: 321-329.

Kopczyńska-Jaworska Bronisława. 1981. Dyskusyjne problemy syntezy badań nad pasterstwem wysokogórskim. „Etnografia Polska” t. XXV, z. 2: 85-96.

Łach Janusz, Musiał Marin. 2015. Przeszłość i znaczenie tradycji dla współczesnego oblicza kulturowego góralszczyzny Beskidu Małego - zapis $w$ krajobrazie. Wrocław: Wydawnictwo Uniwersytetu Wrocławskiego.

Łach Janusz. 2010. Kamienne szopy pasterskie jako ginacy element krajobrazu Beskidu Małego. „Czasopismo Wierchy” t. 76: 244-249.

Moszyński Kazimierz. 1967. Kultura ludowa Stowian. Warszawa: Książka i Wiedza.

Moszyński Kazimierz. 1996. Ludy pasterskie ich kultura materialna oraz podstawowe wiadomości o formach wspólżycia zbiorowego, o wiedzy, życiu religijnym i sztuce. Cieszyn: Wydawnictwo Pro-Filia.

Musiał Marcin. 2010. Śladami kultury góralskiej w Beskidzie Małym. Andrychów: Drukarnia Drukpress s.c.

Myczkowski Zbigniew. 2015. Kompozycyjne i architektoniczne wyznaczniki tożsamości krajobrazów. „Problemy Ekologii Krajobrazu” t. XL: 199-208.

Myga-Piątek Urszula, Chmielewski Tadeusz, Solon Jerzy. 2015. Rola cech charakterystycznych wyróżników $i$ wyznaczników krajobrazu w klasyfikacji i audycie krajobrazów aktualnych. „Problemy Ekologii Krajobrazu” t. XL: 177-185.

Myga-Piątek Urszula. 2012. Krajobrazy kulturowe - aspekty ewolucyjne i typologiczne. Katowice: Wydawnictwo Uniwersytetu Śląskiego.

Niedźwiecka-Filipiak Irena. 2009. Wyróżniki krajobrazu i architektury wsi Polski południowo-zachodniej. Wrocław: Uniwersytet Przyrodniczy we Wrocławiu.

Novák Ján, Podolák Ján, Zuskinová Iveta, Margetín Milan. 2013. Po stopách valachovv Karpatoch. Brno:Tribun EU.

Sobala Michał. 2014. Krajobrazy pasterskie w Polsce i Europie-wybrane typy, przyktady i formy ochrony. „Prace Komisji Krajobrazu Kulturowego” t. 25: 81-98.

Tivodar Mihajlo. 1994. Tradicijne skotarstvo ukraïns'kih Karpat drugoï polovini XIX peršoï polovini XX st. Užgorod: Karpati: 305-329 [Тиводар Михайло. 1994. Традuиіиине скотарство українських Карпат другої половини ХІХ - першої половини XX cm. Ужгород: Карпати: 305-329].

Zawiejska Ewa. 1986. Budownictwo pasterskie w Beskidzie Żywieckim. „Prace i Materiały Muzeum Archeologicznego i Etnograficznego w Łodzi”. Seria Etnograficzna nr 26: $39-55$. 


\title{
AGRO-SHEPHERD BUILDINGS AS A DISTINGUISHING FEATURE OF RESEARCH ON THE TYPOLOGY AND GENESIS OF PASTORAL LANDSCAPES OF THE POLISH-UKRAINIAN PART OF THE OUTER CARPATHIANS
}

\begin{abstract}
The article is an attempt to distinguish - through specific buildings of the agroshepherd economy - new subtypes of pastoral landscapes, which are agro-shepherd landscapes in the area of medium mountain ranges of the Outer Carpathians. The cultural values of the area of the Wallachian genesis classify it as a particularly valuable landscape. This unique legacy has given rise to joint research into the structure and function of the mountain economy in ethno-geographic terms. The aim of the activities is to protect the disappearing, archaic heritage of Wallachian shepherds called "Fathers of Europe".
\end{abstract}

Keywords: The Carpathians, The Little Beskid, The Skole Beskid, pastoralism, agroshepherd economy, Wallachian culture

\section{АГРОПАСТИРСЬКІ СПОРУДИ ЯК ВІДМІННА РИСА ПОЛЬСЬКО-УКРАЇНСЬКОЇ ЧАСТИНИ ЗОВНІШНІХ КАРПАТ}

Резюме: Пропонована стаття це спроба виокремити (на основі своєрідного полонарського господарського будівництва ) новий різновид пастирських ландшафтів, якими, на нашу думку, являються пастирські та сільськогосподарські ландшафти в районі низьких і середніх гір Зовнішніх Карпат. Культурні цінності волоського за походженням району класифікують його як особливо цінний за ландшафтом. Ця унікальна спільна спадщина стала вкладом у польсько-українські дослідження структури та функціонування гірської економіки з етногеографічної точки зору. Метою діяльності стає захист зникаючої, архаїчної спадщини волоських пастухів, яких можна назвати «Отцями Свропи».

Ключові слова: Карпати, Малий Бескид, Сколівський Бескид, скотарство, селянсьво, волоська культура 